\title{
Nonspeaking Children in Schools for Children with Severe Mental Disabilities in the Greater Pretoria Area: Implications for Speech-language Therapists
}

\author{
Juan Bornman and Erna Alant \\ Centre for Augmentative and Alternative Communication \\ Department of Communication Pathology \\ University of Pretoria
}

\begin{abstract}
The aim of this study was to describe children enrolled in registered schools for children with severe mental disabilities in the greater Pretoria area in order to compile a profile of nonspeaking children. Emphasis was placed on the prevalence of nonspeaking children as well as on their functioning in different skill areas in order to assess the need for service delivery. Two questionnaires were developed; the first for obtaining biographical data from teachers; the second for obtaining information on the communication and related abilities of children between $3+12$ years. The particular teachers completed the questionnaires in conjunction with fieldworkers. Results indicated a high prevalence (38\%) of nonspeaking children in schools for children with severe mental disabilities in the Pretoria area and also indicated that they were a heterogeneous group regarding communication and related abilities. This survey was the first.step in determining prevalence and describing nonspeaking children in schools for children with severe mental disabilities in South Africa. Results also indicated that these children are in great need of additional service delivery with special reference to augmentative and alternative communication (AAC) strategy implementation.
\end{abstract}

\section{OPSOMMING}

Die doel van hierdie studie was om kinders ingeskryf by geregistreerde skole vir verstandelik erg gestremde kinders in die groter Pretoria-area te beskryf om sodoende 'n profiel van nie-sprekende kinders saam te stel. Klem is geplaas op die voorkoms van nie-sprekende kinders asook op hulle funksionering met betrekking tot verskillende vaardigheidsareas om sodoende die behoefte aan dienslewering te bepaal. Twee vraelyste is ontwikkel; die eerste vir die verkryging van persoonlike inligting van die betrokke onderwysers en die tweede vir die verkryging van inligting rakende die kommunikasie-en verwante vaardighede van kinders tussen die ouderdomme 3 - 12 jaar. Die betrokke onderwysers het hierdie vraelyste in samewerking met veldwerkers voltooi. Resultate het 'n hoë voorkoms (38\%) van nie-sprekende kinders in skole vir. verstandelik erg gestremde kinders in die Pretoria-area aangetoon, asook dat hulle ' $n$ heterogene groep is met betrekking tot kommunikasie. en verwante vaardighede. Hierdie studie was die eerste stap in die bepaling van die voorkoms en beskrywing van niesprekende kinders in skole vir verstandelik erg gestremde kinders in Suid-Afrika. Resultate het ook aangetoon dat hierdie kinders ' $n$ groot behoefte het aan addisionele dienslewering, met spesifieke verwysing na aanvullende en alternatiewe kommunikasie (AAK) strategie-implementasie.

KEYWORDS: augmentative and alternative communication, nonspeaking children, service delivery, prevalence.

\section{INTRODUCTION}

The devastating effect that the inability to speak has on an individual's daily life has been described extensively during the last two decades by nonspeaking people themselves as well as by those who interact closely with them. Not only does the inability to speak make it more difficult to convey messages and to participate in interactions, it also impacts on language and the development of literacy skills. Kopenhaver and Yoder (1992) pointed out that as many as $80 \%$ of nonspeaking people have very poor literacy skills. Furthermore, they stress that poor literacy skills in this group of people relate not only to the inability of the individual to speak, but also to a lack of expo- sure to literacy experiences. As being nonspeaking is often interpreted by people as an inability to think and learn, these nonspeaking children are frequently denied learning opportunities. Being nonspeaking within a speaking world therefore creates a number of attitudinal barriers that have to be overcome. "Speech is the most important thing we have. It makes us a person and not a thing. No one should ever have to be a "thing" (Joseph, 1986).

It is against this background that two major issues can be identified in the augmentative and alternative communication (AAC) literature. The first relates to the importance of identifying children who are nonspeaking or at risk not to develop speech, and the second focuses on the different ways in which people who are not able to express 
themselves adequately through speech can gain access to other means of communication to prevent the isolation and frustration which is associated with the inability to express oneself.

Various studies have been conducted internationally to establish the prevalence of nonspeaking children within the special school context. Different definitions were used to define nonspeaking, e.g. "persons who have a severe speech problem due to physical, neuromuscular, cognitive or emotional deficits and not due primarily to hearing impairment" (Matas, Mathy-Laikko, Beukelman and Legresley 1985). Bloomberg and Johnson (1990) expanded on this definition by defining the nonspeaking population as "persons who are temporarily or permanently unable to meet all their communication needs verbally". The North Dakota survey, however, aimed at quantifying the term nonspeaking by defining it as "People who use 15 or less intelligible words" (Burd, Hammes, Bornhoeft and Fisher, 1988). This cut-off point was utilized in this study on the assumption that with normal development, speech becomes a functional means of communication towards the end of the single word stage, when a typical expressive vocabulary consists of $15-20$ words (Cantwell and Baker, 1985).

It was further decided to use the term "nonspeaking" as opposed to "nonverbal" as the latter is an ambiguous term which technically means "without language", and is thus not used for describing individuals, but rather for describing evaluation tools (e.g., nonverbal intelligence of individuals who have difficulty comprehending or producing spoken language) (Lloyd, Fuller and Arvidson, 1996).

The North Dakota survey reported that $2,4 \%$ of children in special schools in North Dakota were nonspeaking (Burd, et al., 1988). It further indicated a strong decrease (almost 50\%) in the prevalence of non-speech after three years of schooling. Matas et al., 1985, conducted a similar survey in Washington State's special schools and included urban and rural populations. Results from this demographic study indicated that $3,6 \%$ children of the urban and $6 \%$ children of the rural special schools were nonspeaking. In another study, which was conducted in Germany and which included the whole school population, it was reported that $0,35 \%$ of all school children were nonspeaking (Coon, Kremer and Hildebrand, 1992). When these demographic surveys were extended to include the total population, a prevalence rate of $0,12 \%$ was found in a study conducted in Australia (Bloomberg et al., 1990). It is interesting to note that all these studies were conducted in Western countries. No similar studies have been conducted in developing countries.

As far as nonspeaking people's access to AAC systems is concerned, the Washington survey reported that at least $18 \%$ of children in special education used some type of AAC system, whilst $23,3 \%$ were being trained to use an AAC system (Matas et al., 1985). The other $29,2 \%$ were using only unintelligible speech and although the rest of the children met the criteria for using an AAC system, they were in need of initial or follow-up evaluations. In the German survey it was reported that the majority of children used unaided communication systems (facial expressions, followed by gestures, touching, and pointing respectively) (Coon et al., 1992). These results are further supported by results from the Washington survey which also reported that nonspeaking children use gestures and emotional reactions (e.g., facial expressions and gross body movements) as the predominant communication system (Matas et al., 1985). This tendency also seems to be present in older children, as a survey amongst university students also found gestures to be the most frequently used system (Huer, 1991).

As previously mentioned no studies have as yet been conducted in Africa on the prevalence of nonspeaking children. This lack of descriptive statistics provided the major impetus for this survey. In order to assist professionals in planning intervention for nonspeaking children, a profile of the nonspeaking population in South Africa is needed. It is against this background that the present study aimed at describing the communication abilities of children in schools for children with severe mental disabilities.

\section{METHOD}

\section{AIM}

The main aim of this study was to establish the prevalence of nonspeaking children enrolled in schools for children with severe mental disabilities in the greater Pretoria metropolitan substructure and by compiling a profile regarding their functioning in different skill areas (cognitive, motor, sensory, communication and social). In addition, their exposure to intervention was also described.

\section{RESEARCH DESIGN}

In order to realise the aims of the study an analytical (quantitative) survey design was used as this type of design is particularly useful in describing demographic information within a particular context (Groenewald, 1986).

\section{SUBJECTS}

\section{Description of schools}

All registered schools for children with severe mental disabilities within a particular geographical area, namely the greater Pretoria metropolitan substructure (including Pretoria Central, Eersterust, Laudium, Atteridgeville and Mamelodi) were included. Criteria for inclusion in the different schools varied, although certain broad principles remained the same, i.e. an IQ of between 30 - 60 (measured as reliable as possible), age between $3-18$ years at admission, a physical ability to move about and an ability at admission to show communication potential. These schools were selected as the candidacy for the use of AAC strategies and techniques is high within these schools and they consequently form one of the primary focus areas in the AAC field (Matas et al., 1985). These schools all had to be registered with one of the following departments prior to 1995 : Department of Education and Training, Department of Education and Culture or the Department of Health. No informal schools were included. Schools for the deaf and schools for the blind were also excluded as they were traditionally not the main area of focus when using AAC strategies (Coon et al., 1992 and Bloomberg et al., 1990). This brought the total number of schools to 10 . More detailed information on these schools is presented in Table 1.

According to Table 1 there was a broad variation in the schools. Some schools had a large number of pupils (School No 6), whilst others had relatively few (School No 2). Some schools also had assistance from therapists (Schools No 1 and 9) whilst others had no therapists (Schools No 8 and 
10). All the schools had class aids to assist the teachers.

\section{Description of teachers}

Teachers acted as the main informants for this survey, as various national (Skuy, Westaway, Makula and Perold, 1988) and international studies (Matas, et al., 1985) confirmed that teachers can meaningfully describe pupils functioning. It is thus important to provide a brief description of the teachers. Information related to relevant biographical information regarding the teachers was obtained from Questionnaire I (Bornman, 1995). This was a short 2-page questionnaire that was completed by a fieldworker in conjunction with a teacher. The total number of teachers included in the survey was 55 . This questionnaire revealed that $98 \%$ of teachers were female.

Table 2 indicates that the teachers were a heterogeneous group regarding qualifications, training and years of teaching experience. Regarding qualifications, it was found that $82 \%$ of the teachers had post-matric training, whilst $18 \%$ had only school training varying from Std 8 - Std 10. Fifteen teachers reported that they had no special training for working with children with severe mental disabilities, whilst 40 teachers reported that they had some spe-

TABLE 1 : Description of schools included in the study

\begin{tabular}{|c|c|c|c|c|c|c|c|c|c|}
\hline \multirow[t]{2}{*}{$\#$} & \multirow[t]{2}{*}{ Area } & \multicolumn{2}{|c|}{$\begin{array}{l}\text { \# of } \\
\text { pupils }\end{array}$} & \multicolumn{2}{|c|}{$\begin{array}{c}\text { \# of } \\
\text { teachers }\end{array}$} & \multirow{2}{*}{$\begin{array}{l}\text { \# of } \\
\text { class } \\
\text { aids }\end{array}$} & \multirow{2}{*}{$\begin{array}{l}\text { \# of } \\
\text { speech } \\
\text { therapists }\end{array}$} & \multirow[t]{2}{*}{$\begin{array}{l}\text { \# of } \\
\text { OT's }\end{array}$} & \multirow{2}{*}{$\begin{array}{c}\text { \# of } \\
\text { physio- } \\
\text { therapists }\end{array}$} \\
\hline & & $\mathrm{T}$ & I & $\mathrm{T}$ & $\mathrm{I}$ & & & & \\
\hline 1 & Pretoria Central & 115 & 53 & 12 & 6 & 12 & 2 & 2 & 3 \\
\hline 2 & Pretoria Central & 18 & 11 & 3 & 3 & 2 & 0 & 0 & $\begin{array}{l}1 \text { twice } \\
\text { a week }\end{array}$ \\
\hline 3 & Eersterust & 47 & 23 & 5 & 4 & 2 & $\begin{array}{l}1 \text { twice } \\
\text { a week }\end{array}$ & $\begin{array}{l}1 \text { once } \\
\text { a week }\end{array}$ & $\begin{array}{l}1 \text { physio } \\
\text { assistant }\end{array}$ \\
\hline 4 & Pretoria Central & 30 & 15 & 3 & 2 & 4 & $\begin{array}{l}1 \text { once } \\
\text { a week }\end{array}$ & $\begin{array}{l}1 \text { once } \\
\text { a week }\end{array}$ & $\begin{array}{l}1 \text { once } \\
\text { a week }\end{array}$ \\
\hline 5 & Soshanguve & 110 & 25 & 6 & 3 & 2 & 0 & 1 & 0 \\
\hline 6 & Pretoria Central & 336 & 125 & 34 & 16 & 10 & 0 & 1 & 0 \\
\hline 7 & Laudium & 57 & 35 & 5 & 4 & 7 & 1 & 1 & 0 \\
\hline 8 & Mamelodi & 78 & 21 & 4 & 3 & 3 & 0 & 0 & 0 \\
\hline 9 & Pretoria Central & 60 & 39 & 12 & 10 & 6 & 1 & 1 & 0 \\
\hline 10 & Atteridgeville & 120 & 65 & 11 & 4 & 4 & 0 & 0 & 0 \\
\hline & TOTAL & 971 & 412 & 95 & 55 & & & & \\
\hline
\end{tabular}

Legend : $T=$ Total number at school $; I=$ Number included in survey

TABLE 2: Biographical information of teachers

\begin{tabular}{|c|c|c|c|c|c|c|c|}
\hline \multicolumn{8}{|c|}{ QUALIFICATIONS } \\
\hline \multicolumn{2}{|c|}{$\begin{array}{l}\text { Less than } 10 \text { years } \\
\text { at school }\end{array}$} & \multicolumn{2}{|c|}{$\begin{array}{l}10-12 \text { years at } \\
\text { school }\end{array}$} & \multicolumn{2}{|c|}{$\begin{array}{c}2 \text { - } 3 \text { years after } \\
\text { school }\end{array}$} & \multicolumn{2}{|c|}{$\begin{array}{l}\text { More than } 4 \text { years } \\
\text { after school }\end{array}$} \\
\hline $\mathrm{n}=6$ & $11 \%$ & $\mathrm{n}=4$ & $7 \%$ & $\mathrm{n}=39$ & $71 \%$ & $\mathrm{n}=6$ & $11 \%$ \\
\hline \multicolumn{8}{|c|}{ SPECIAL TRAINING * } \\
\hline \multicolumn{2}{|c|}{$\begin{array}{l}\text { In-service training: } \\
\text { less than } 2 \text { years }\end{array}$} & \multicolumn{2}{|c|}{$\begin{array}{l}\text { Diploma: } \\
\text { less than } 1 \text { year }\end{array}$} & \multicolumn{2}{|c|}{$\begin{array}{l}\text { Diploma: } \\
\text { Less than } 2 \text { years }\end{array}$} & \multicolumn{2}{|c|}{$\begin{array}{c}\text { Diploma: } \\
\text { Less than } 3 \text { years }\end{array}$} \\
\hline $\mathrm{n}=15$ & $27 \%$ & $\mathrm{n}=5$ & $9 \%$ & $\mathrm{n}=10$ & $18 \%$ & $\mathrm{n}=10$ & $18 \%$ \\
\hline \multicolumn{8}{|c|}{ YEARS OF TEACHING EXPERIENCE AT SCHOOLS FOR CHILDREN WITH MENTAL DISABILITIES } \\
\hline \multicolumn{2}{|c|}{ Less than 1 year } & \multicolumn{2}{|c|}{$1-2$ years } & \multicolumn{2}{|c|}{$3-5$ years } & \multicolumn{2}{|c|}{ More than 5 years } \\
\hline $\mathrm{n}=\mathbf{3}$ & $5 \%$ & $\mathrm{n}=3$ & $5 \%$ & $\mathrm{n}=13$ & $24 \%$ & $\mathrm{n}=36$ & $66 \%$ \\
\hline
\end{tabular}

* Please note that 15 teachers had no special training, and thus the total $n=40$. 
cial training, ranging from in-service training to special diplomas. The majority of teachers had less than 2 years of in-service training. Of the 25 teachers with special diplomas, 5 had diplomas of less than 1 year and 10 had diplomas of less than 2 years and less than 3 years respectively. Furthermore it was found that 36 of the teachers had more than 5 years teaching experience at schools for children with severe mental disabilities, whilst only 3 had less than 1 year experience.

\section{Description of children}

Information regarding the children was obtained from the teacher and recorded in Questionnaire II. A total number of 412 children was included as they met the set criteria, namely that their chronological ages had to be between 3,0 and 12,11 years (only children from the preprimary and primary school phase were included) and the children's names had to appear on the class list. When referring to the total number of children, it would amount to 412 children, and when referring to the nonspeaking children it would amount to 158 children. As previously mentioned, nonspeaking children were classified as children who spoke 15 words or less (Burd et al., 1988). More detailed information on the children included in the survey follows in the "Results" section.

\section{PROCEDURE}

\section{MATERLAL}

For the purpose of this study two questionnaires were developed, one for descriptive biographical information about the teacher; and the second for information about each individual child in the class. The contents of both questionnaires were based on those used in the international demographic surveys on the nonspeaking children (Bloomberg et al., 1990; Matas et al., 1985; Coon et al., 1992 and Burd et al., 1988). Questionnaire I dealt with the biographical details of the teachers and covered aspects such as identifying data (name of school, number of children in the class, and gender), qualifications, years of experience, specialized training, and whether the teacher received any additional assistance from class aids, therapists or volunteers (Bornman, 1995). Questionnaire II covered the children's background information (gender and birth date), information on the functioning in different skill areas (communication, cognition, motor, sensory and socioemotional), literacy skills (reading, writing and mathematical) as well as intervention. This information, as well as the particular 5 point rating scale that was used, is described in more detail in Appendix A.

\section{DATA COLLECTION}

The data collection procedure required that both Questionnaire I and Questionnaire II be tested in a pilot study, after which certain revisions were made. Permission to conduct this survey was then obtained from the local school authorities and 5 fieldworkers were trained in completing both questionnaires effectively and efficiently by providing them with the necessary skills and knowledge. Fieldworkers were placed individually at the 10 schools, and after the principal had introduced them to the various teachers and the aims of the survey had been ex- plained, the fieldworkers started completing the question. naires in conjunction with the teachers. As the fieldworker had face to face contact with the teachers, they clarified additional questions that seemed confusing to individual teachers. A total number of 55 teachers and 412 childre were included in the survey. All questionnaires were then encoded, and the data analyzed using a variety of statisti. cal procedures.

\section{ANALYSIS OF DATA}

Data was analyzed and statistically processed in order to provide quantitative results of the survey. Statistical procedures included descriptive statistics (discrete frequency distribution counts and percentages) and logistic regression procedures (in order to determine which variable(s) were the best predictors of non-speech). These variables were selected by means of a stepwise selection procedure (PROC LOGIST of SAS). Loglinear correlation coefficients were also applied to the data (in order to de. termine the strength of the relationship(s) between variables). This procedure was conducted in the following way: firstly a chi-square test was applied to a table and if significant dependencies were found on the $5 \%$ level, the loglinear model was applied to measure the strength of the relationships between the variables. A critical value of $z=\geq 42,58$ was used to judge whether a particular variable was significant. The P4F procedure of the BMPD statistical package was used for the loglinear analysis.

\section{RESULTS AND DISCUSSION}

To accurately describe the prevalence of nonspeaking children it is important to provide a comprehensive overview of all the children included in the survey. It is for this reason that all the figures include both the speaking $(n=254)$ and nonspeaking $(n=158)$ children.

\section{BACKGROUND INFORMATION}

From Figure 1 it is clear that $38 \%$ of children between the ages 3,0 - 12,11 years in schools for children with severe mental disabilities in the greater Pretoria area were nonspeaking. As previously mentioned, "nonspeaking" referred to children "who use 15 or less intelligible words"

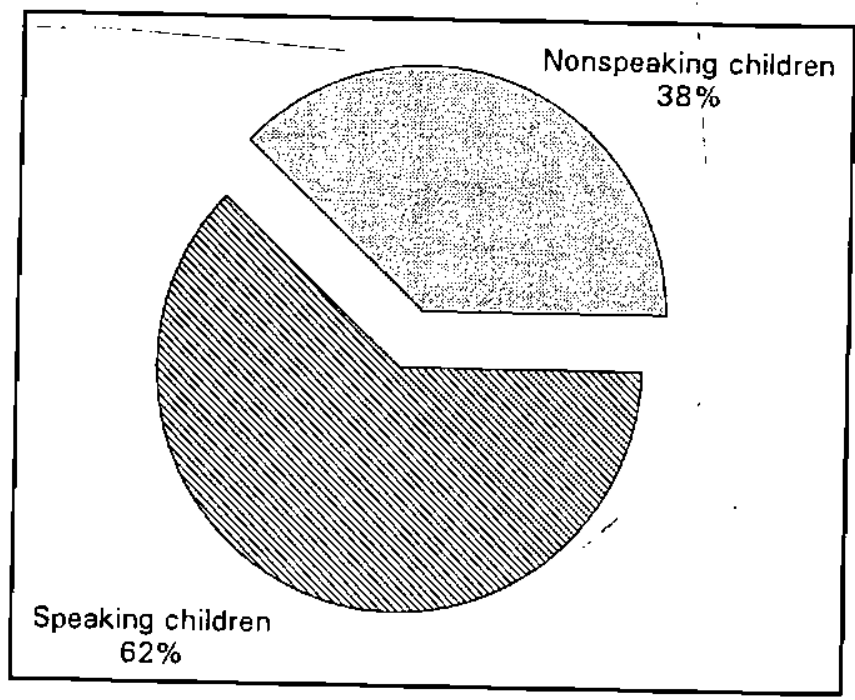

FIGURE 1 : Prevalence of nonspeech 


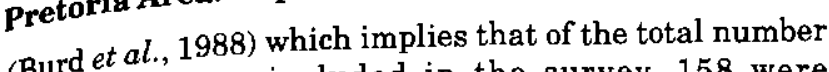
(Burd et children included in the survey, 158 were of 412 childr. The high prevalence figure $(38 \%)$ of nonspeaking children was the most significant factor in nonspeake this research. Thable international surveys which reported of other compare of $3,5-6 \%$ (Matas et al., 1985). The lower incidence of nonspeaking children $(3,5 \%)$ was reported in urban schools, and $6 \%$ in rural/remote schools implying that the prevalence of the present study might have been higher if rural schools had been included (Matas et al., 1985; Aie llo, 1980).

When comparing speaking and nonspeaking children under the age of 6 included in the survey, it is clear that more nonspeaking children are placed in schools for children with severe mental disabilities than their speaking counterparts. However, at the age of 6 , the number of speaking and nonspeaking children are almost even. The majority of nonspeaking children was 9 years old. The number of 13 year olds is very low, due to the fact that children older than 12 years and 6 months were rounded off to 13 years, and children older than 12 years and 11

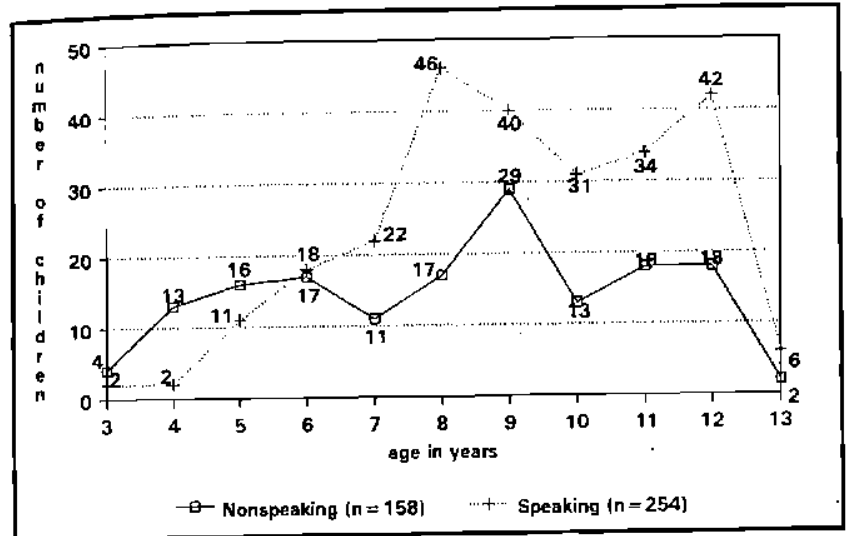

FIGURE 2 : Ages of the children

TABLE 3: Gender of children

\begin{tabular}{|l|c|c|}
\hline Variable & $\%$ Boys & $\%$ Girls \\
\hline Total group of children & $66 \%$ & $34 \%$ \\
\hline Nonspeaking children & $68 \%$ & $32 \%$ \\
\hline
\end{tabular}

months were excluded. The majority of nonspeaking children was 9 years old, with a greater distribution at the ages higher than 9 , indicating that more children were older, rather than younger than 9 . However, before age 6 (when speaking and nonspeaking children are almost even) the survey indicated that there are more nonspeaking children than speaking children in these schools. This could indicate that because the lack of verbal speech is relatively easily identified by parents, they tend to send nonspeaking children to school at a relatively young age. International prevalence data by Burd et al. (1988) suggests that changes in oral communication in special schools are unlikely after the age of 7 . As the highest percentage of nonspeaking children in this survey was older than 7 years, the data could suggest that the possibility of changing from nonspeaking to speaking is slight. Another factor confirming this finding is that a lack of speech by school entry is predictive of a poor outcome for learning to speak (Burd et al., 1988). Emphasis on AAC systems should therefore be a priority in special schools as such a high percentage of children within these schools are AAC candidates.

Regarding the gender of the nonspeaking children, a binomial procedure (non-parametric test) was applied to the data, which had a value of $\geq 226$, implying that there are significantly more nonspeaking boys than girls. The ratio of $2: 1$ (male:female) which was found in the total group of children prevailed in the nonspeaking group were a male:female ratio of 2,1:1 was reported. In other similar surveys, the male:female ratio was not as significant as in this survey, e.g., 1,4:1 in the Australian survey (Bloomberg et al., 1990), 1,6:1 in the Scottish survey (Murphy, Marková, Moodie, Scott \& Boa, 1993) and 1,6:1 in the German survey (Coon et al., 1992). Consequently it can be stated that in this study significantly more boys than girls were described as nonspeaking.

\section{COMMUNICATION ABILITIES}

Regarding the communication abilities of nonspeaking children, a number of factors were significant predictors of non-speech. Table 4 describes the results obtained where the variables related to communication were tested against non-speech by means of the loglinear model.

The interaction between non-speech and receptive language is highly significant. In cases where the children displayed very poor or poor receptive language skills, they spoke significantly less than 15 words, and when they dis-

TABLE 4: Communication abilities of the children

\begin{tabular}{|l|l|l|l|l|l|l|}
\hline \multirow{2}{*}{ Variable } & \multirow{2}{*}{$\begin{array}{l}\text { Nonspeaking } \\
\text { or Speaking }\end{array}$} & \multicolumn{5}{|c|}{ z-Values (z= _, 2,58) } \\
\cline { 3 - 7 } & & Very poor & Poor & Some & Reasonable & Normal \\
\hline Receptive language & Nonspeaking & $* 7,177$ & $* 3,052$ & $-3,456$ & $-4,645$ & $-1,366$ \\
& Speaking & $-7,177$ & $-3,052$ & $* 3,456$ & $* 4,645$ & 1,366 \\
\hline Ability to speak sentences & Nonspeaking & $* 8,545$ & 0,135 & $-3,047$ & $-3,738$ & $-0,706$ \\
& Speaking & $-8,545$ & $-0,135$ & $* 3,047$ & $* 3,738$ & 0,706 \\
\hline Understandability of commu- & Nonspeaking & $* 2,758$ & 1,885 & 0,971 & $-4,645$ & $-1,366$ \\
nication attempts & Speaking & $-2,758$ & $-1,885$ & $-0,971$ & $* 4,645$ & 1,366 \\
\hline
\end{tabular}

All variables that indicate a significant correlation with nonspeech on a $95 \%$ confidence level, are marked with an asterisk (*). 
played some to reasonable function, they spoke significantly more than 15 words.

The generally poor expressive ability is further highlighted by the poor ability to use sentences (i.e. putting together two words or more). Results indicated that nonspeaking children (thus children who were speaking 15 words or less) had a very poor ability to use sentences (they were thus not verbally putting any words together). This would indicate that speech is so limited for school purposes that it precludes functional oral communication. Children speaking more than 15 words, however, were rated as having some, or reasonable functioning in speaking sentences.

Regarding how understandable teachers rated the children's communication attempts, it was found that the understandability of the nonspeaking children's attempts were rated as very poor, whilst the understandability of the speaking children's communication attempts were rated as reasonable.

Teachers were asked to rate communication desire with the following question "Does the child try to communicate with people?" From Figure 3 it is clear that when looking at nonspeaking children's communication desire it became evident that $89 \%$ of them did have the desire to communicate. Lack of communication desire can thus not be interpreted as a major factor contributing to the high prevalence of nonspeaking children.

A significant interaction between means of communication and non-speech was found when a Pearson chisquare test was performed on the data. Results are shown in more detail in Figure 4.

AAC systems (including typing, writing and/or communication boards) were used only $0,79 \%$ of the time in the nonspeaking population (this percentage was rounded off to $1 \%$ ). In comparison with the other means of communication that was used at least $8 \%$ of the time, it is clear that AAC systems were used significantly less (Figure 4). The second lowest means of communication is that of understandable speech (8\%). These two variables are significantly lower than the third lowest means of communication, touching and gestures which are both present in $17 \%$ of the cases. The nonspeaking children used vocalizations as their most frequent means of communication (20\%) followed by facial expressions (19\%) and head nodding to indicate yes/no (18\%).

When looking at the high percentage of nonspeaking children, and the fact that $89 \%$ of them indicated a desire to communicate, it is to be expected that the number of: children who use some sort of AAC system to compensate would also be high, but this was not the case. The use of any AAC system, aided (e.g., typing, writing or communication boards) or unaided (e.g., gestural systems) occurred infrequently in nonspeaking children $(0,79 \%$ of the time). None of the nonspeaking children used typing, writing or high technology systems.

The German study (Coon et al., 1992), reported that the majority of children used unaided AAC systems, with facial expressions as the means most frequently used, followed by gestures, touching and pointing respectively. This correlates with the findings of the present survey which reported that $17-19 \%$ of children used facial expressions, head-nodding to indicate yes and no, natural gestures and touching (See Figure 4). These results are further supported by results from the Washington State survey, which also reported that nonspeaking children used gestures/ emotional reactions as the predominant communication system (Matas et al., 1985). This could be due to the fact that in the past nonspeaking children did not receive AAC system intervention, and had to rely on natural gestures to make their needs known. The lack of skills training in the past thus resulted in children mostly using natural ways of communicating, as these natural ways were demonstrated in their environments (e.g., most people use facial expressions, head-nodding and natural gestures). Furthermore, these unaided systems are, of course, always readily available. However, as people begin to realize the importance of communication intervention for nonspeaking children with the consequent development of cognitive abilities by giving nonspeaking children entrance into abstract thought, the use of more formal aided and unaided systems will increase, as it gives these children access to more extensive communication systems.

In the past, in South Africa, much emphasis was placed on the use of speech as the only way of communicating. For a great number of people the ability to communicate is equal to the ability to speak. Nonspeaking children could not express themselves verbally and were therefore less frequently understood by teachers and their communication ability was also described as significantly poorer than that of speaking children (See Table 4). The most frequently used means of communication were vocalizations (unintelligible speech) for the nonspeaking group, followed by facial expressions (19\%) and head nodding (18\%) (See Figure 4). These findings correlate with those of the German study which also reported that speech was rated as the major means of communication (Coon et al., 1992). This

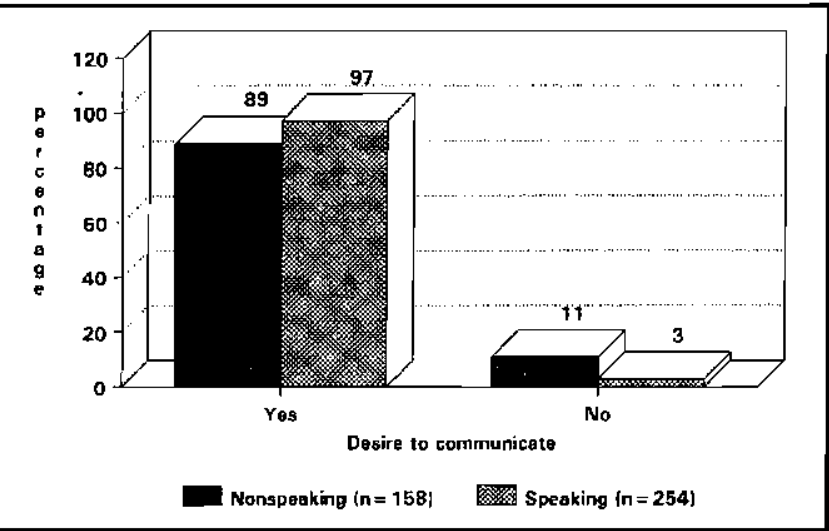

FIGURE 3 : Communication desire

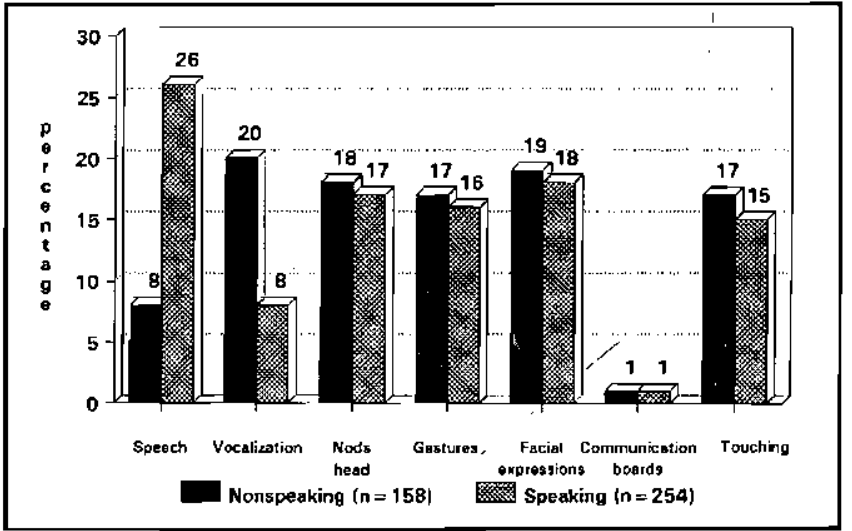

FIGURE 4 : Communication means 
might be a reflection of the attitudes regarding AAC systems which prevail where information regarding these gystems is limited and where they are mostly unknown. Contrary to research which has proved that the use of AAC systems enhances communication and facilitates speech development, uninformed people hesitate to use AAC systems as they fear that this might inhibit or prevent speech development as the AAC systems might reduce motivation for speech communication (Silverman, 1995). Thus, in countries where service providers do not have knowledge and skills regarding AAC systems and AAC does not have a strong basis for service delivery the tendency to aim at speech development was observed. This tendency was not noted in any of the other countries in which AAC had been in use for some time (Murphy et al., 1993 and Matas et al., 1985).

The general abilities of the total group of children are displayed in Figure 5 and Figure 6. In both of these figures a rating scale of 1 - 5 was used. One is indicative of very poor to almost no functioning, 2 of poor functioning, 3 of some functioning, 4 of reasonable functioning and 5 of normal functioning for chronological age (Bornman, 1995).

\section{GENERAL ABILITIES IN DIFFERENT SKILL AREAS}

Percentages displayed on Figure 5 and Figure 6 were calculated to be proportionally correct for each variable. Each variable discussed thus represents the proportional percentage.

Results from Figure 5 show that children whose cognitive ability was rated as very poor spoke significantly less than 15 words. On the other hand, children who were rated as having reasonable cognitive functioning spoke significantly more than 15 words.

Results from Figure 5 also show that for both gross and fine motor ability there was a significant interaction between these motor abilities and non-speech. Results indicated that with very poor and poor gross motor functioning children spoke significantly less than 15 words, and with reasonable to normal functioning children spoke significantly more than 15 words. Children who were rated as having very poor or poor fine motor abilities spoke significantly less than 15 words whilst children with reasonable fine motor abilities spoke significantly more than 15 words.

The loglinear model also șhowed a meaningful interac-

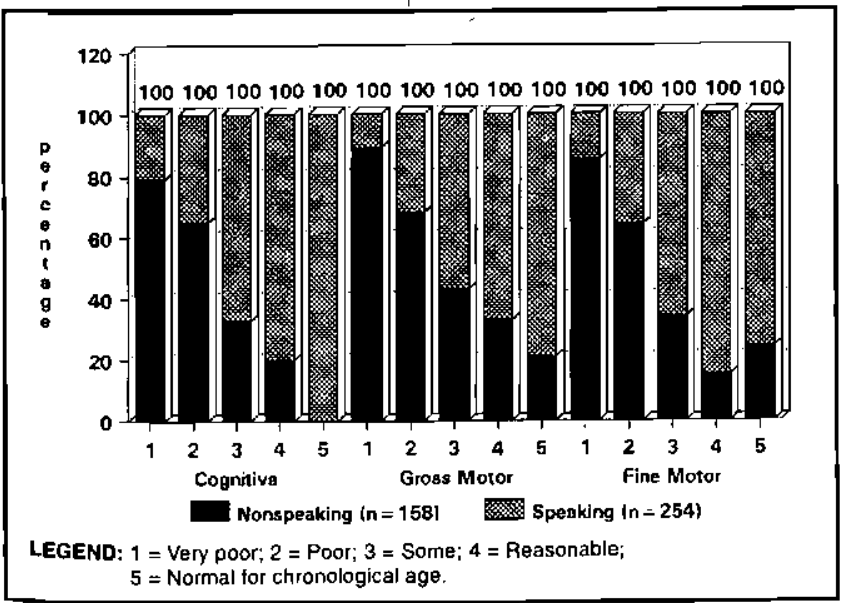

FIGURE 5 : Cognitive and motor abilities tion between communication (with both adults and peers) and social ability with non-speech, as displayed in Figure 6 . When communication ability with adults was rated as very poor to poor, children spoke significantly less than 15 words, and when communication ability was rated as reasonable to normal, children spoke significantly more than 15 words. Exactly the same tendency was found in the case of communication with peers, but the significance was even stronger in the latter case. A highly significant interaction between non-speech and social ability was also found. Children who spoke less than 15 words were regarded as having very poor to poor social ability, and children speaking more than 15 words were rated as having reasonable to normal social ability.

It is clear from the results obtained in the present survey that although the children's abilities varied in the different skill areas (motor, cognitive, communication and social), certain tendencies prevailed. The data indicated that when speaking and nonspeaking children's abilities were compared, nonspeaking children were rated as having significantly poorer abilities than the speaking children. This finding suggests that the abilities of the nonspeaking children might have been underestimated due to the fact that teachers do not understand these children well.

As confirmation of the above, the poor communication skills of the nonspeaking children inevitably lead to poor social skills. It was clear from the results that the nonspeaking children's social abilities were mostly rated as "poor" and "very poor" whilst the majority of speaking children's abilities were rated as "good". This could be due to the fact that communication attempts from the nonspeaking children are ignored, overlooked or misinterpreted, which results in poor understanding of their intentions, which leads to increased isolation.

Figure 7 differentiates between the type of therapy (speech, occupational or physio-) received by the nonspeaking children as opposed to the speaking children as well as to whether the therapy was conducted on an individual or group basis.

\section{THERAPY}

Apart from physiotherapy, nonspeaking children received less speech and occupational therapy than their speaking counterparts. Furthermore, children received group speech and occupational therapy rather than indi-

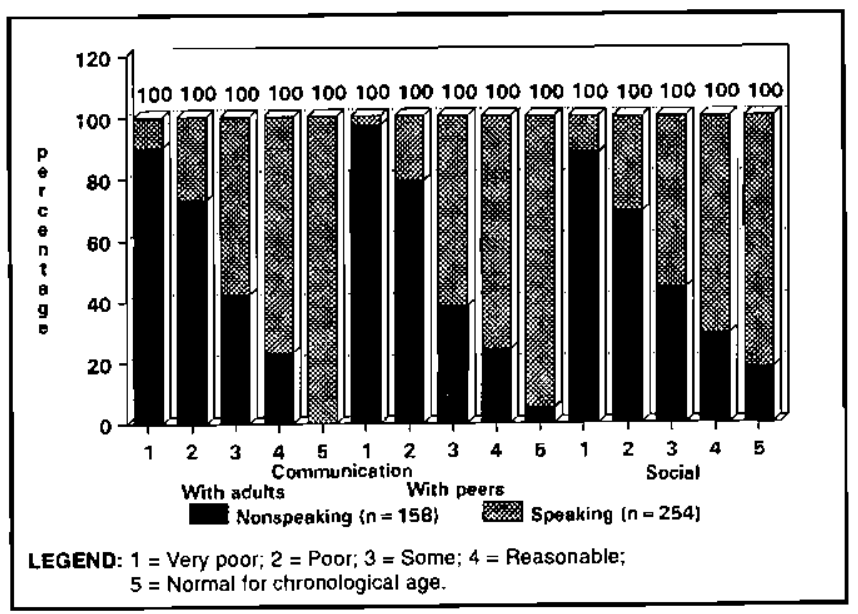

FIGURE 6 : Communication and social abilities 
vidual therapy. However, regarding physiotherapy, the majority of children received individual therapy. The majority of children receiving physiotherapy was nonspeaking. The therapy provided to the nonspeaking children varied from less than half an hour per week to more than five hours per week. The majority of children receiving therapy also received group rather than individual therapy. It could be due to the fact that most schools in the survey had a limited number of therapists, resulting in high caseloads. In order to address these caseloads and to serve as many children as possible, therapists mostly provided group therapy. The effectiveness of the therapy was not measured in this study, but the high number of nonspeaking children possibly suggests that the current therapy is not as effective and meaningful as it could be.

It is furthermore important to note that AAC is a relatively new field in South Africa, therefore a strong basis for the use of AAC systems within special education has not yet been laid. Until recently speech therapists received no training in the use of AAC strategies and thus, although $29 \%$ of the children received some kind of speech therapy, the nature of this therapy is unclear (See Figure 7).

Apart from requiring special training in working with children with special needs, service providers require familiarity and experience with the range of AAC systems, aids, symbols and strategies available in order to equip them with knowledge and skills related to AAC (Blackstone, 1990). As AAC is a relatively new field of expertise in South Africa, not many therapists and/or teachers (the primary AAC service providers) receive any training in AAC techniques during their undergraduate training (Alant and Emmett, 1995). In Scotland, however, where AAC has been in use for some time, the Scottish survey also reported that the training of SLP's should be addressed, as they do not receive knowledge and skill training related to AAC (Murphy et al., 1993). Knowledge and skill alone are not sufficient, there is also a strong need for the development of interdisciplinary AAC service delivery. This can be developed by exposing SLP students to work with professionals from other disciplines in order to help them develop a more holistic approach to AAC (Huer, 1991).

In the present study it was found that nonspeaking children received considerably less therapy than speaking children (See Figure 7). As previously mentioned this might be due to the fact that service providers do not have the knowledge and skills necessary for working with this specific population. It might also be due to the attitudes

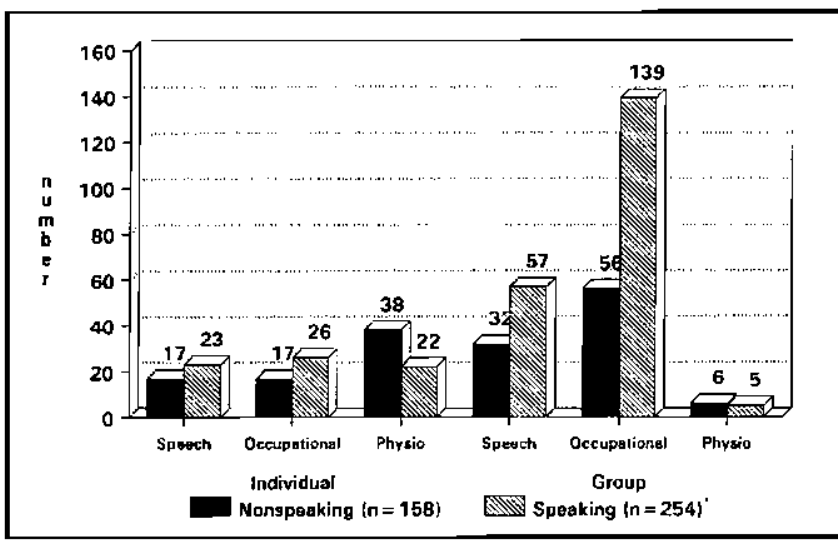

FIGURE 7 : Type of therapy received of service providers that nonspeaking children have a poor prognosis of developing in the various skill areas and thus the focus of service delivery is placed on the speaking chil. dren. These attitudes are interlinked with low expectations of nonspeaking children, as service providers often do not expect any progress from them (Shrewsbury, Lass and Joseph, 1985).

Finally, another factor negatively affecting the services provided to nonspeaking children is the lack of a support. ive infrastructure. Therapists often work in isolated contexts and resources are not readily available. Some schools included in the survey did not have therapists, and service provision is the responsibility of the teachers. As teach. ers do not have the skills and training to implement AAC strategies without a supportive infrastructure, the implementation of these strategies become a low priority.

\section{CONCLUSIONS}

Nonspeaking children in schools for children with severe mental disabilities in the greater Pretoria area constitute a large population with heterogeneous character. istics and abilities, who need intensive, specialized therapy and AAC services. However, for a number of reasons, the nonspeaking population is underserved. This is due to the limited number of therapists working in special education (See Table 1) as well as limited specialized knowledge and skills regarding AAC strategies and low expectations from nonspeaking children due to attitudinal problems (Shrewsbury et al., 1985). The results of this survey indicate a strong need for additional in-service and undergraduate training for professionals who serve the nonspeaking population. Further research is also necessary to help improve the quality of service delivery to the nonspeaking population.

\section{ACKNOWLEDGEMENT}

The financial assistance of the Centre for Science Development (HSRC, South Africa) towards this research is hereby acknowledged. Opinions expressed and conclusions arrived at are those of the author and are not necessarily to be attributed to the Centre for Science Development.

\section{REFERENCES}

Aiello, S.C. (1980). Non-oral communication survey: A onecountry needs assessment and demographic study. Unpublished educational study. California: Plavan School.

Alant, E. and Emmett, T. (1995). Breaking the silence : Communication and education for children with severe handicaps. Pretoria : Human Sciences Research Council.

Blackstone, S.W. (ed.): (1990). How you can use demographics to provide better service delivery in AAC. ACN News, 3(4), pp $1-7$

Bloomberg, K. and Johnson, H. (1990). A statewide demographic survey of people with severe communication impairments. AAC Augmentative and Alternative Communication, 6(1), pp 50-60.

Bornman, J. (1995). Nonspeaking children in schools for children with mental handicaps in the Pretoria area: A survey of communication and related problems. M.Communication Pathology thesis. Pretoria: University of Pretoria. (Unpublished).

Burd, L., Hammes, K., Bornhoeft, D.M and Fisher, W. (1988). A North Dakota prevalence study of nonverbal school-age children. Language Speech and Hearing Services in Schools, 19(4), pp 371-383.

Cantwell, D.P. and Baker, L. (1985). Speech and language: 
Development and disorders. In Calculator, S.N. and Bedrosian, J (eds). Communication assessment and intervention for adults with mental retardation. Boston : Little Brown and Company.

Coon, R., Kremer, G. and Hildebrand, M. (1992). A demographic analysis of people with speech impairments in West Berlin, Germany. Unpublished presentation at ISAAC Biennial Conference, Philadelphia.

Groenewald, J.P. (1986). Social research: Design and analysis. Stellenbosch: University Publishers and Booksellers.

Huer, M.B. (1991). University students using augmentative and alternative communication in the USA: A demographic study. AAC Augmentative and Alternative Communication, 7(4), pp 231-239.

Joseph, D. (1986). The morning. Communication Outlook, 8(2), 8.

Kopenhaver, D.A. and Yoder, D.E. (1992). Literacy learning of children with severe speech and physical impairments in school settings. Seminars in Speech and Language, 13(2), pp 143-153.

Lloyd, L., Fuller, D. and Arvidson, H. (1988). Glossary. In: Lloyd, L., Fuller, D. and Arvidson, H. (Eds). Augmentative and Alternative Communication. New York: Allyn Bacon.

Matas, J.A., Mathy-Laikko, P., Beukelman, D.R. and Legresley,
K. (1985). Identifying the nonspeaking population: A demographic study. AAC Augmentative and Alternative Communication, 1(1), pp 17-31.

Murphy, J., Marková, I., Moodie, E., Scott, J. and Boa, S. (1993). Augmentative and alternative communication systems used by people with cerebral palsy in Scotland: A demographic survey. Final report to the Scottish Council for Spastics. Stirling: University of Stirling.

Shrewsbury, R.G., Lass, H.J. and Joseph, L.S. (1985). A survey of special educators' awareness of, experiences with, and attitudes towards nonverbal communication aids in the schools. Language, Speech and Hearing Services in Schools, 16(4), pp 293-298.

Silverman, F.H. (1995). Communication for the speechless. Needham Heights : Allyn and Bacon.

Skuy, M., Westaway, M., Makula, N. and Perold, C. (1988). Development of a screening instrument for the identification of pupils with impairments. South African Journal of Education. 8(1), pp 45-49.

UNICEF. (1993). Children and women in South-Africa: A situation analysis. Johannesburg: UNICEF and NCRC.

Yach, D. (ed). (1991). Challenging health in South Africa: Towards new perspectives in research. California: The Henry J. Kaiser Family Foundation.

\section{APPENDIX A : Description of Questionnaire II}

\begin{tabular}{|c|c|}
\hline Description of childrens' abilities & Rating scale (if any) \\
\hline Identification data: gender, age. & * Explanatory notes on categories can be found in Bornman (1995). \\
\hline $\begin{array}{l}\text { Areas of functioning } \\
\text { Cognitive } \\
\text { Motor } \\
\text { Sensory (visual \& auditory) } \\
\text { Communication, } \\
\text { Social }\end{array}$ & $\begin{array}{l}1=\text { Almost no function } \\
2=\text { Poor function } \\
3=\text { Some function } \\
4=\text { Reasonable function } \\
5=\text { Normal function }\end{array}$ \\
\hline $\begin{array}{l}\text { Communication skills } \\
\text { Receptive language } \\
\text { Expressive language } \\
\text { Communication mode }\end{array}$ & $\begin{array}{l}\text { Receptive language abilities were scored on a } 5 \text { point Likert scale that } \\
\text { ranges from a child who understands very limited instructions to a child } \\
\text { who understands everything. Expressive language was scored in terms of } \\
\text { the number of words the child was able to produce intelligibly. If the child } \\
\text { was unable to produce more that } 15 \text { words intelligibly, he/she was labelled } \\
\text { as nonspeaking (Burd et al., 1988). Communication means included ver- } \\
\text { bal, gestures, facial expressions, sign language, pointing to pictures, ob- } \\
\text { jects and symbols, writing and or typing, yes/no indication and vocaliza- } \\
\text { tion. A question on the frequency with which the teacher understood the } \\
\text { communication of the student was also included. }\end{array}$ \\
\hline Reading skills & $\begin{array}{l}1=\text { No interest in books } \\
2=\text { Interest in books } / \text { likes handling them } \\
3=\text { Sight vocabulary more than } 30 \text { words } \\
4=\text { Reads easy sentences, but not age appropriate } \\
5=\text { Adequate reading for chronological age }\end{array}$ \\
\hline Writing skills & $\begin{array}{l}1=\text { No interest in writing or scribbles } \\
2=\text { Makes letters and letter like shapes } \\
3=\text { Makes letters and tries to write words } \\
4=\text { Writes most things, but not age appropriate } \\
5=\text { Adequate writing skills for chronological age }\end{array}$ \\
\hline Number concept & $\begin{array}{l}1=\text { Cannot count, or counts without number concept } \\
2=\text { Number concept up to } 5 \\
3=\text { Knows concept "more } / \text { less" up to } 5 \\
4=\text { Able to do simple mathematics, but not age appropriate } \\
5=\text { Adequate mathematical skills for chronological age }\end{array}$ \\
\hline $\begin{array}{l}\text { Therapy received: } \\
\text { Speech therapy } \\
\text { Occupational therapy } \\
\text { Physiotherapy }\end{array}$ & $\begin{array}{l}\text { A filter question was used (yes, no) as not all children received therapy. In } \\
\text { applicable cases teachers had to specify the type of therapy received, and } \\
\text { whether it was group- or individually-based. }\end{array}$ \\
\hline
\end{tabular}



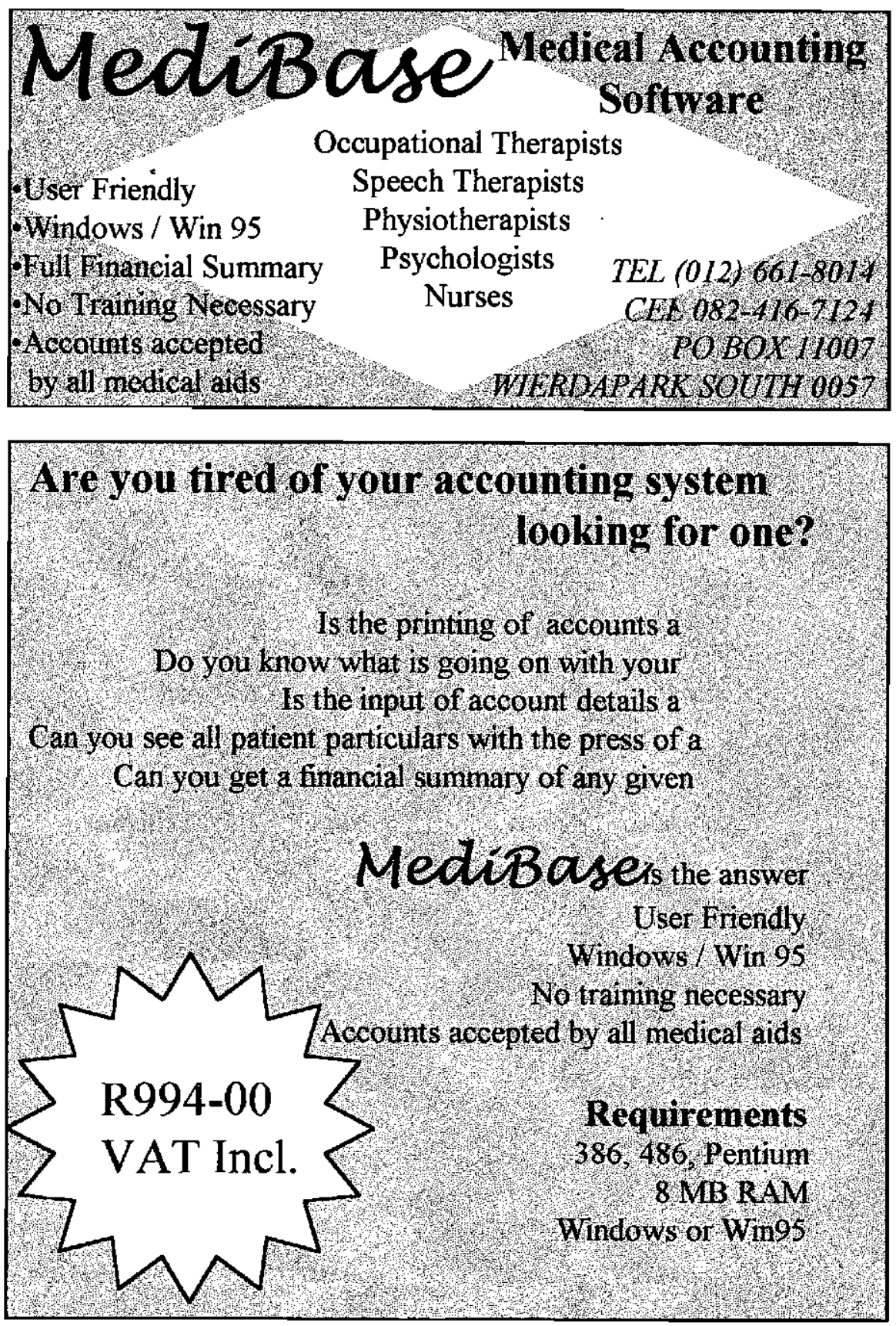